\title{
Fracture Healing Research-Shift towards In Vitro Modeling?
}

\author{
Moritz Pfeiffenberger 1,2, Alexandra Damerau 1,2@ , Annemarie Lang 1,2,3@ , Frank Buttgereit ${ }^{1,2}$, Paula Hoff ${ }^{1,4}$ \\ and Timo Gaber $1,2, *(\mathbb{D})$
}

1 Department of Rheumatology and Clinical Immunology, Charité-Universitätsmedizin Berlin, Corporate Member of Freie Universität Berlin and Humboldt-Universität zu Berlin, 10117 Berlin, Germany; moritz.pfeiffenberger@charite.de (M.P.); alexandra.damerau@charite.de (A.D.); annemarie.lang@charite.de (A.L.); frank.buttgereit@charite.de (F.B.); paula.hoff@charite.de (P.H.)

2 German Rheumatism Research Centre Berlin (DRFZ), The Leibniz Institute, 10117 Berlin, Germany

3 McKay Orthopaedic Research Laboratory, Department of Orthopaedic Surgery, University of Pennsylvania, Philadelphia, PA 19104, USA

4 Endokrinologikum Berlin, Medizinisches Versorgungszentrum (MVZ) am Gendarmenmarkt, 10117 Berlin, Germany

* Correspondence: timo.gaber@charite.de; Tel.: +49-030-4505-13364

Citation: Pfeiffenberger, M.;

Damerau, A.; Lang, A.; Buttgereit, F.;

Hoff, P.; Gaber, T. Fracture Healing

Research—Shift towards In Vitro

Modeling? Biomedicines 2021, 9, 748.

https://doi.org/10.3390/biomedicines 9070748

Academic Editor:

Alireza Dolatshahi-Pirouz

Received: 5 May 2021

Accepted: 23 June 2021

Published: 28 June 2021

Publisher's Note: MDPI stays neutral with regard to jurisdictional claims in published maps and institutional affiliations.

Copyright: (C) 2021 by the authors Licensee MDPI, Basel, Switzerland. This article is an open access article distributed under the terms and conditions of the Creative Commons Attribution (CC BY) license (https:/ / creativecommons.org/licenses/by/ $4.0 /)$.

\begin{abstract}
Fractures are one of the most frequently occurring traumatic events worldwide. Approximately $10 \%$ of fractures lead to bone healing disorders, resulting in strain for affected patients and enormous costs for society. In order to shed light into underlying mechanisms of bone regeneration (habitual or disturbed), and to develop new therapeutic strategies, various in vivo, ex vivo and in vitro models can be applied. Undeniably, in vivo models include the systemic and biological situation. However, transferability towards the human patient along with ethical concerns regarding in vivo models have to be considered. Fostered by enormous technical improvements, such as bioreactors, on-a-chip-technologies and bone tissue engineering, sophisticated in vitro models are of rising interest. These models offer the possibility to use human cells from individual donors, complex cell systems and 3D models, therefore bridging the transferability gap, providing a platform for the introduction of personalized precision medicine and finally sparing animals. Facing diverse processes during fracture healing and thus various scientific opportunities, the reliability of results oftentimes depends on the choice of an appropriate model. Hence, we here focus on categorizing available models with respect to the requirements of the scientific approach.
\end{abstract}

Keywords: fracture healing; bone tissue engineering; in vivo models; in vitro models

\section{Introduction}

Bone fractures are among the most common types of traumatic events worldwide. Indeed, the treatment itself leads to a high economic burden for the society. Despite sophisticated therapeutic strategies, aggravating circumstances such as delayed fracture healing or non-union, which occur in about $10 \%$ of fractures, lead to a prolonged regeneration process and thus to a burden for the affected patients. In particular, high-risk groups such as patients with osteoporosis, the elderly or malnourished, post-menopausal women or patients with impaired blood supply are vulnerable to the development of fracture healing disorders. To investigate processes of adequate or impaired fracture healing in more detail, various in vivo, ex vivo or in vitro models exist to provide the opportunity for targeted and focused scientific basic and translational research.

\section{Fracture Healing}

Usually, bone is composed of an organic part (20-40\%) and an inorganic part (50-70\%), while water retention (5-10\%) and lipids (<3\%) represent the remaining components. The organic matrix is mainly composed of collagens providing elasticity and flexibility to the bone, while the inorganic part accounts for mechanical stiffness and load-bearing capacity 
due to the characteristic composition of its extracellular matrix. The latter consists mainly of hydroxyapatite, which is composed of phosphate and calcium. However, significant amounts of bicarbonate, sodium, potassium, citrate, magnesium, carbonate, fluorite, zinc, barium and strontium are also found [1]. On the cellular level, bone is composed of osteoblasts, osteocytes and osteoclasts [2]. Osteoblasts, which synthesize new bone matrix and build up the soft osteoid that is not yet fully mineralized, derive from osteoprogenitor cells and build bone tissue, creating the basis for bone growth and remodeling [3]. Osteoblast-derived osteocytes are by far the most abundant cell type in bone. They cannot divide, have a characteristic star-shaped morphology, and are essential for calcium homeostasis and maintenance of the bone matrix [4]. In addition, osteocytes coordinate the skeletal response to mechanical loading by sensing the mechanical stress and thus coordinate both bone formation and bone resorption [5]. In contrast, osteoclasts originate from the monocyte/macrophage lineage and are capable of resorbing bone, which is why they are essential for bone remodeling [6]. Healthy bone is dynamically remodeled by permanently breaking down old bone and forming new bone [6]. The ossification process during bone regeneration can be divided into endochondral and intramembranous ossification [7]. Briefly, endochondral ossification is characterized by the conversion of hypertrophic chondrocytes into bone. The chondrocytes themselves are formed by mesenchymal condensation of recruited MSCs. Ossification of hypertrophic chondrocytes is followed by controlled bone growth and remodeling processes to form and shape bone. In contrast, in intramembranous ossification, bone is developed directly from the original primitive mesenchymal tissue without cartilage apposition [8-10]. Of note, bone is one of the few tissues in the human body that can heal without scarring [11]. To achieve the pre-injury state and restore the functionality of the traumatized bone, the organized exchange between different cell types (e.g., immune and skeletal cells) and, above all, the spatial and temporal distribution of these cells, are fundamental [12].

Fracture healing can be divided into four different phases (Figure 1). The inflammatory phase comes first and includes the typical formation of a fracture hematoma, which occurs right after fracture and lasts 1-3 days in mice and 1-5 days in humans. Characteristic features of the initial phase of fracture healing include the formation of the fracture hematoma, a restricted oxygen supply characterized by a hypoxic microenvironment, limited nutrient supply and a local inflammation process, resulting in cell activation and migration [13]. Subsequently, the second phase follows, where fibrocartilaginous callus is formed, followed by the third phase, where the fibrocartilaginous callus is substituted by a bony callus.

Within the fourth and last phase, which completes the process of fracture healing, bone is entirely remodeled, and compact bone is added [14].

In a bone fracture, the traumatic event can disrupt adjacent blood vessels that supply nutrients and oxygen to both the bone and the periosteum, and even the bone marrow canal. Cells from the blood vessels and the bone marrow coagulate in the fracture gap (e.g., immune cells, erythrocytes, hematopoietic progenitor cells and MSCs), hence forming the so-called fracture hematoma $[15,16]$. In the second phase, pro-angiogenic cytokines such as VEGF, platelet-derived growth factor (PDGF) and IL-8 trigger angiogenic processes and thus initiate the restoration of vascular network and thus the supply of nutrients and oxygen [17]. Restoration of the vascular network is a critical event not only in bone repair but also in bone development. Thus, osteogenesis and angiogenesis have to be tightly and timely linked to ensure cell survival and ultimately successful fracture healing [18,19]. The well-known pro-angiogenic vascular endothelial growth factor (VEGF) plays a critical role during these processes. However, VEGF levels also have to be tightly and timely regulated, since pathophysiological levels impair bone regeneration by reducing osteoblast differentiation and increasing osteoclast-mediated bone resorption [20]. Thus, disturbances in angiogenesis are linked to the development of fracture healing disorders such as delayed unions or non-unions $[21,22]$. 


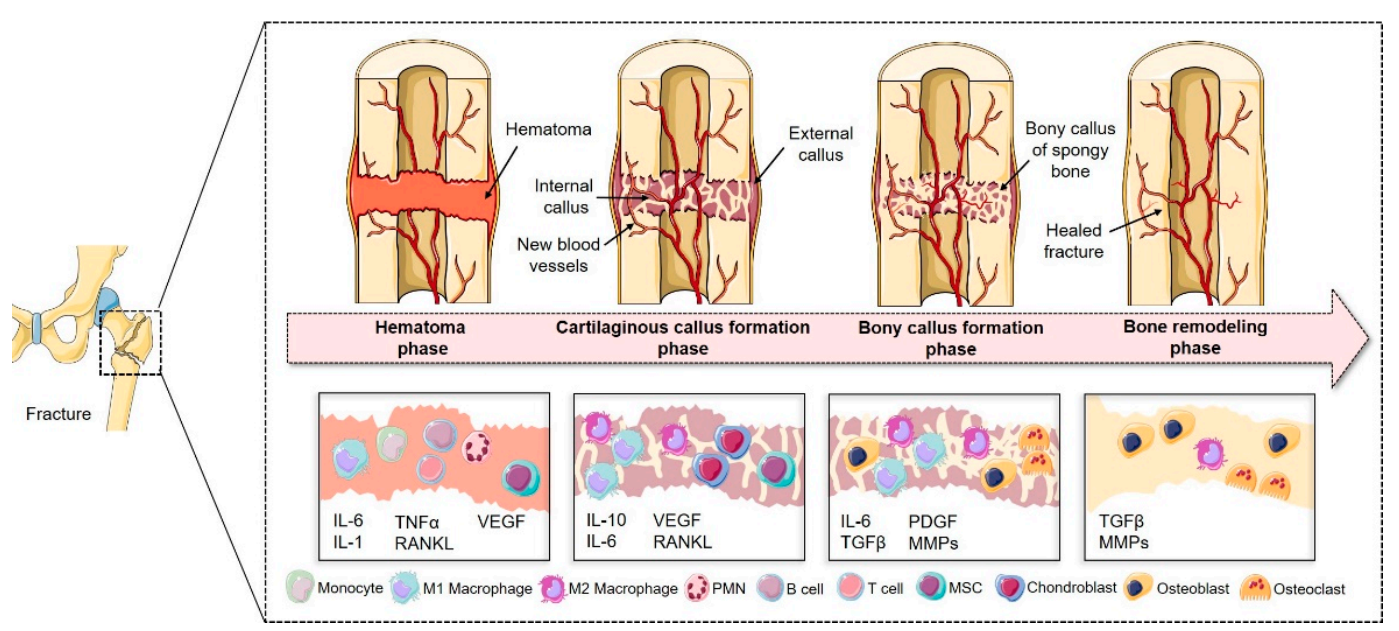

Figure 1. Schematic description of the four phases of fracture healing: The first phase is characterized by the formation of the fracture hematoma and a local inflammation. Immune cells, such as peripheral multinucleated cells (PMN), T- and B-cells, monocytes and MSCs, are activated and recruited towards the fracture gap via autocrine and paracrine pathways (e.g., by the release of cytokines such as interleukin (IL-1), IL-6 or tumor necrosis factor (TNF $\alpha$ )). Activation of, for instance, vascular endothelial growth factor (VEGF) also paves the way for revascularization in this early phase. In the following phase, chondroprogenitor cells differentiate into chondroblasts and start to build an early fibrocartilaginous bridging area, while angiogenic processes are also upheld. The third phase is characterized by endochondral ossification, thereby substituting cartilage with primitive bone tissue. In the last phase bone structure and function is completely restored by the constrict interplay of bone-forming and bone-resorbing cells. Figure was modified from Servier Medical Art, licensed under a Creative Common Attribution 3.0 Generic License.

However, the restoration of the vascular network not only supplies the developing cartilaginous callus with oxygen and nutrients, but also with cells such as MSCs supporting the regeneration process. Recruitment of MSCs towards the fracture site is supported by the fibrin-rich granulation tissue in the fracture hematoma. The recruited MSCs differentiate into chondroblasts and subsequently start chondrogenesis, forming a fibrocartilaginous network, which is bridging the bony ends of the fracture site. MSC-derived and recruited osteoprogenitor cells generate an initial layer of woven bone by rapid deposition of minerals $[16,23]$. In contrast to lamellar bone, woven bone is characterized by an arbitrary organization of collagen fibers, high cellularity and low mineral density [24].

The next phase is ushered in when the cartilaginous soft callus is resorbed and/or calcified. Ossification of hypertrophic chondrocytes and calcium deposition by osteoblasts derived from recruited MSCs lead to the formation of the soft and later the hard callus. Continuous blood vessel formation and sprouting during this process further supports the recruitment of MSCs towards the immature callus. During this phase, osteoblasts and osteoclasts invade and repeatedly remodel the hard callus. In a highly orchestrated manner, osteoclasts resorb, and osteoblasts form new bone, thereby completely replacing the center region of the corticalis with compact bone, while the callus ends, and the woven bone are replaced with lamellar bone. The vascular network is also remodeled, which ultimately leads to the complete regeneration of the functional bone structure $[16,23,25,26]$.

\section{Clinical Relevance of Fractures}

In routine clinical practice, fractures are often evaluated and treated in terms of the type of trauma. Recent recommendations advise against classifying trauma into high- or low-trauma and fragility fractures (osteoporotic fractures). Recovery of bone structure and functionality does not depend on the type of fracture, but does depend on a correlation of high- and low-trauma fractures with low bone mineral density and future fracture risk [27-33]. 
Irrespective of the type of trauma, fractures and their follow-up costs display a high economic burden for the society [34]. The number of especially fragile fractures is expected to double between 2010 and 2040 [34]. Unfortunately, a high treatment gap exists between patients that are at risk for fractures but do not receive any appropriate treatment $[35,36]$. Worldwide, about 9 billion osteoporotic fractures occur annually [37]. Every second woman and every fourth man will suffer from an osteoporotic fracture during their lifetime [38]. However, it is not only the partly protracted rehabilitation process and the possible reduced quality of life after fracture that matter, but hip and vertebral fractures are associated with increased mortality of about $25 \%$ in the first year after fracture $[35,38]$. The highest risk factor for a following fracture is the first occurrence of a fracture. After menopause, the relative risk of a following fracture is more than quintupled within the first year after fracture in women [39]. Thus, the identification and treatment of patients of risk for fractures exhibits a great medical need. We already have potent and well-established drugs for the treatment of osteoporosis (anti-resorptive and osteoanabolic drugs) [40-43]. However, the prophylaxis of osteoporosis and their consequences is unfortunately not that established as it is for e.g., high blood pressure, myocardial infarction, stroke, dyslipidemia or breast cancer $[37,44,45]$. Furthermore, a heterogeneous group of patients with restricted immune functions comprising inter alia patients with autoimmune diseases, malignancies, diabetics, elder people and even alcoholics often suffer from prolonged or inadequate fracture healing [46-52]. These patients tend to a development of pseudarthrosis [47,48,53]. It is estimated that about $10 \%$ of fractures do not heal uneventfully, with non-unions being the most feared complication [54]. A non-union is defined as a fracture that persists for a minimum of 9 months without signs of healing for 3 months, while in delayed unions there is a failure to reach union by 6 months [55]. Both delayed unions and non-unions are complex orthopedic problems that are most often multifactorial. Patient-specific clinical factors and the type of fracture are among the items that merit consideration in treatment. These include poor living habits such as poor nutrition or smoking, but also biologic causes of poor blood flow and poor bone healing, which include diabetes, peripheral vascular disease, vitamin D deficiency, renal insufficiency and medications such as glucocorticoids, nonsteroidal anti-inflammatory drugs (NSAIDs) and opiates. Therapeutically, several modalities usually have to be applied. Treatment requires a multifaceted approach, which includes initial non-operative (e.g., fracture brace, immobilization in a cast, pulsed lowintensity ultrasound or other external bone stimulation) and operative treatment options (e.g., compression plates, exchange nailing, dynamization of nail, internal fixation with biologic stimulation and bone grafting). Clinical monitoring during therapy requires continuous assessment of clinical symptoms such as pain and radiographic findings over time. In addition, the patient's comorbidities must be considered, because action may be needed to mitigate the resulting risk factors for poor bone healing [55].

Thus, fractures and their consequences are of high interest in current and future medical care. To summarize the medical needs, we on the one hand have to better identify and treat patients at risk to prevent fractures. On the other hand, regarding the aging society and thus growing population of patients with restricted immune functions, we have to prevent and improve/accelerate inadequate fracture healing.

To test potential procedures or drugs that could be used in the second area, several in vitro approaches have been developed [56-58]. One can speculate that the possibility of testing hypotheses in in vitro models before needing animal experiments will not only contribute to the welfare of animals but also accelerate the research process.

\section{Modeling Fracture Healing In Vivo-Animal Models}

Animal models are used to (i) study and understand the complex processes of human disorders in a physiological acting organism (basic research) and (ii) to test and verify new therapeutic approaches including medication and biomaterials for regenerative bone reconstruction, implants and fixation approaches as well as surgical procedures (translational research) [59]. Overall, more than half of the animals used in orthopedic research are rats 
or mice [60]. Rodent models are commonly used for basic research issues because they have high reproductive rates and low housing requirements, and thus minimize costs. The genome in most rodents is fully decoded and offers the possibility of genetic manipulation. There are also a variety of well-established analytical tools available. Translational research usually follows a two-step approach in which a new therapeutic approach is first developed and tested in a rodent model (e.g., mouse or rat), followed by evaluation in a large animal model (e.g., sheep or pig).

The development of more sophisticated osteosynthesis techniques incorporating clinically oriented stabilization methods has led to the increasing use of small rodents (including rabbits; $>80 \%$ overall) in bone healing research [60,61]. These techniques, which are standardized and reproducible, allow accurate recapitulation of clinical scenarios, including delayed and impaired fracture healing that may be found in human patients. Looking at osteosynthesis techniques from a mechanical point of view, the stiffness of fixation, the degree of interfragmentary motion or even the lack of fixation can have a tremendous impact on the outcome of bone regeneration [62]. Well-established models include the osteotomy of long bones-commonly femur or tibia-from mice and rats, which uses external fixators, plates or intramedullary pin/locking nails to stabilize the osteotomized bone [60]. Briefly, osteotomy describes the creation of a fracture gap with tools such as Gigli wire saws, scalpels or scissors resulting in a defined gap varying between $1-8 \mathrm{~mm}$ in rats and $0.1-4 \mathrm{~mm}$ in mice. However, there is an ongoing discussion whether the outcomes of osteotomies are comparable and translatable to random, more natural fractures $[63,64]$. In addition to osteotomy, methods such as the 3-point bending system or the Einhorn device are useful to design a fracture scenario as naturally as possible by applying high mechanical forces to induce bone trauma.

Impaired fracture healing scenarios can be created by unstable fixation, critical size defects, cauterization of the periosteum or removal of the bone marrow and the addition of comorbidities such as polytrauma or ovariectomy (osteoporosis) [62,65]. In addition to the different types of surgical techniques (open/closed), different fracture gap sizes, fracture configurations, or certain additional injuries in the periosteum or soft tissues, specifications of the mouse strain, sex and age must also be considered when selecting the appropriate model, as all of these factors may influence the results and thus the translational potential of the study $[66,67]$.

Translational studies usually use large animal models to mimic the biomechanical requirements in human patients. In this case, instruments and materials are used that are also used in clinical routine on the same scale, e.g., nails, plates and fixators [68]. In contrast to rodents, large animals have a higher similarity to humans in terms of weight, load-bearing capacity and mechanical forces. They are therefore very well suited for testing new implants, scaffolds and fixations for their biomechanical stability. Furthermore, the size of the long bones in large animal models allows the generation of very natural bone defects, e.g., to test the biocompatibility, integrity and durability of biomaterials or synthetic implant materials also over longer periods of time [69]. These models with natural bone defects without osteotomy are generated, for example, by adapted bending methods including torsional or rotational forces to induce e.g., spiral fractures or are even generated by means of gunshots to mimic shock models concomitant with soft tissue injuries.

In principle, animal models reach their limits if they are to represent the human organism with all its biological properties (Table 1). In particular, most animals display only slight similarities with respect to the macro- and microstructure of the human bone. For instance, main differences in the structure of long bones between mice and humans are (i) a permanently open growth plate in the epiphyses, (ii) the absence of a Haversian system and (iii) a low proportion of cancellous bone in the epiphyses [70,71]. In contrast, sheep and pig bones have comparable macrostructure but differ in microstructure from those of humans. Nevertheless, bone density and fracture stress value are similar to pigs but also dogs are similar to those of humans [72]. 
Table 1. Overview of the usability of various animal models [73,74].

\begin{tabular}{|c|c|c|c|}
\hline Species & $\begin{array}{c}\text { Purpose: } \\
\text { Basic Research }\end{array}$ & $\begin{array}{c}\text { Purpose: } \\
\text { Translational Research }\end{array}$ & $\begin{array}{l}\text { Similarity to Human Patient: } \\
\text { Bone Parameters * }\end{array}$ \\
\hline Mouse & $\begin{array}{l}\text { To gain knowledge on molecular } \\
\text { processes of fracture healing under } \\
\text { physiological and } \\
\text { pathophysiological conditions }\end{array}$ & $\begin{array}{l}\text { To identify therapeutic targets, target } \\
\text { engaged biomarkers and to evaluate the } \\
\text { therapeutic effect of e.g., new compounds }\end{array}$ & $\begin{array}{l}\text { Macrostructure + } \\
\text { Microstructure + } \\
\text { Remodeling + }\end{array}$ \\
\hline Rat & $\begin{array}{l}\text { To gain knowledge on biomechanical } \\
\text { and molecular processes of fracture } \\
\text { healing under physiological and } \\
\text { pathophysiological conditions }\end{array}$ & $\begin{array}{l}\text { To identify therapeutic targets, target } \\
\text { engaged biomarkers and to evaluate the } \\
\text { therapeutic effect of e.g., new compounds } \\
\text { or biomaterials for therapeutic purposes }\end{array}$ & $\begin{array}{l}\text { Macrostructure + } \\
\text { Microstructure + } \\
\text { Remodeling + }\end{array}$ \\
\hline Sheep & $\begin{array}{l}\text { To gain knowledge on biomechanical } \\
\text { and molecular processes of fracture } \\
\text { healing under physiological and } \\
\text { pathophysiological conditions }\end{array}$ & $\begin{array}{l}\text { To evaluate the therapeutic effect of e.g., } \\
\text { new compounds or biomaterials for } \\
\text { therapeutic purposes and surgical } \\
\text { procedures, materials and implants }\end{array}$ & $\begin{array}{c}\text { Macrostructure ++ } \\
\text { Microstructure ++ } \\
\text { Remodeling ++ } \\
\text { Macrostructure +++ } \\
\text { Microstructure + } \\
\text { Remodeling ++ } \\
\text { Macrostructure ++ } \\
\text { Microstructure ++ } \\
\text { Remodeling +++ }\end{array}$ \\
\hline
\end{tabular}

\footnotetext{
* + similar, ++ more similar, +++ highly similar.
}

As outlined before, rodents are especially used for basic research purposes. In Europe, all statistics on animals used in basic and translational research (including all vertebrates) must be reported and published by the European Commission under the Directive 2010/63/EU. The current report (2015-2017) states an overall use of 9 million animals (6 million mice, 1 million rats) in 2017 [75]. Of these, approximately 100,000 animals were used in basic research on the musculoskeletal system while approximately 40,000 animals were used in translational and applied research on human musculoskeletal diseases. These numbers further support the potential of more sophisticated in vitro approaches to reduce the number of animals used in musculoskeletal research. However, in the United States, the Animal Welfare Act does not cover mice and rats. Although they are protected by other regulations, they are not counted. Official statistics exclude mice and rats and therefore, only report the use of 780,070 animals in 2018 [76]. However, the estimated number of animals used in research is approximately 11-23 million including mice and rats [76]. According to NIH reports on funding shares, the budget for musculoskeletal disease research is less than $2 \%$ [77]. Based on these data, it can be assumed that approximately $220,000-460,000$ animals ( $2 \%$ of the estimated total) have been used in musculoskeletal research, which represents a great potential for reduction and replacement. In vitro or ex vivo models cannot currently replace animal models, but they represent an intermediate stage that can be used, for example, to obtain data on the behavior of an active ingredient in the human body that may differ from data obtained in animal studies, ultimately significantly reducing the number of animals that would otherwise be used.

\section{Modeling of Fracture Healing In Vitro}

In addition to animal models (in vivo models), in vitro models are promising tools to mimic and explore in detail various sub-aspects or key aspects of bone healing research. These in vitro models are often based on bone tissue engineering (BTE) strategies (Table 2). They are broadly categorized into scaffold- and hydrogel-based approaches, scaffold-free approaches using spheroid cultures or mesenchymal condensation techniques, and more comprehensive, advanced model systems that implement single and multiple different cell types with and without perfusion or whole tissue explants [78]. The latter are also known as ex vivo bone models and include mainly explants from animal bone tissue. Recently, both the properties and the implications of ex vivo bone models have been excellently reviewed by Cramer et al. [79] and are therefore not part of the review presented here. 
Table 2. Overview of various BTE strategies.

\begin{tabular}{|c|c|c|c|c|c|}
\hline Approach & Materials & Origin & Benefits & Limitations & Refs. \\
\hline \multirow{5}{*}{ Scaffold-based } & Metal & Synthetic & $\begin{array}{l}\text { - } \text { Biocompatibility } \\
\text { - Material strength } \\
\text { - Mechanical properties }\end{array}$ & $\begin{array}{l}\text { Biodegradability } \\
\text { Release of ions }\end{array}$ & {$[80,81]$} \\
\hline & $\begin{array}{l}\text { Fibrin } \\
\text { Collagen } \\
\text { Chitosan } \\
\text { Silk } \\
\text { HA } \\
\text { Starch }\end{array}$ & Natural & $\begin{array}{l}\text { - Biocompatibility } \\
\text { - Biodegradability } \\
\text { - Biofunctionality } \\
\text { - Low immunogenicity } \\
\text { - Biomimetic }\end{array}$ & $\begin{array}{l}\text { Mechanical } \\
\text { properties } \\
\text { Endotoxins }\end{array}$ & [82-87] \\
\hline & $\begin{array}{l}\text { PHA } \\
\text { PGA } \\
\text { PLLA } \\
\text { PEG } \\
\text { PCL }\end{array}$ & Synthetic & $\begin{array}{l}\text { - } \text { Biocompatibility } \\
\text { - Wide material range } \\
\text { - Control over physical properties }\end{array}$ & $\begin{array}{c}\text { Acidic } \\
\text { degradation } \\
\text { Hydrophobicity }\end{array}$ & [88-93] \\
\hline & Bioceramics & Synthetic & $\begin{array}{l}\text { - Osteoinductivity } \\
\text { - Host-tissue similarities } \\
\text { - } \text { Delivery of bioactive molecules }\end{array}$ & $\begin{array}{c}\text { Brittleness } \\
\text { Biodegradability }\end{array}$ & {$[94,95]$} \\
\hline & Bioglass & Synthetic & - Osteoinductivity & $\begin{array}{c}\text { Brittleness } \\
\text { Manipulation }\end{array}$ & [96] \\
\hline Spheroid-based & $\begin{array}{c}\text { MSCs } \\
\text { Osteoblasts } \\
\text { iPSCs } \\
\text { Combination of cells } \\
\text { Cell lines }\end{array}$ & Natural & $\begin{array}{l}\text { - } \text { Biocompatibility } \\
\text { - Biomimetic } \\
\text { - Low immunogenicity } \\
\text { - Cells and own ECM } \\
\text { - Easy to produce/handle } \\
\text { - Implementation of various cell types }\end{array}$ & $\begin{array}{l}\text { Mechanical } \\
\text { properties } \\
\text { Necrotic center }\end{array}$ & [97-101] \\
\hline $\begin{array}{l}\text { Scaffold- and } \\
\text { Spheroid-based }\end{array}$ & & $\begin{array}{c}\text { Synthetic and } \\
\text { natural }\end{array}$ & $\begin{array}{ll}\text { - } & \text { 3D bioprinting } \\
\text { - } & \text { Variety of composites } \\
\text { - } & \text { Morphology }\end{array}$ & $\begin{array}{l}\text { Nutrient supply } \\
\text { Vascularization } \\
\text { Necrotic center }\end{array}$ & {$[101,102]$} \\
\hline $\begin{array}{l}\text { Continuative } \\
\text { Systems }\end{array}$ & $\begin{array}{c}\text { MSCs } \\
\text { Osteoblasts } \\
\text { iPSCs } \\
\text { Combination of cells } \\
\text { Cell lines } \\
\text { Implementation of } \\
\text { non-bone cells }\end{array}$ & Natural & $\begin{array}{l}\text { - Nutrient support } \\
\text { - Vascularization } \\
\text { - Crosstalk of tissues } \\
\text { - } \text { More systemic approach }\end{array}$ & Work in progress & {$[103,104]$} \\
\hline
\end{tabular}

\subsection{Scaffold-Based Model of Bone Regeneration}

Currently, most in vitro approaches focusing on bone regeneration are based on the BTE strategy. This strategy uses 3D scaffolds seeded with cells or cells in combination with bioactive molecules to develop an osteogenic replacement for bone defects. In general, BTE is built on the following pillars [105]:

(i) Mimicking the extracellular bone matrix by using biocompatible scaffolds;

(ii) Using osteogenic progenitor cells or osteogenic cells capable of forming bone tissue matrices;

(iii) Inducing differentiation of the implemented cell types toward the desired phenotype through morphological signals;

(iv) Supporting the growing tissue with oxygen and nutrients by fully restoring vascularity.

Therefore, many new scaffolds have been developed that are able to closely mimic the mechanical and structural properties of bone and, in combination with cells, induce tissue formation [106]. There are a variety of options for the colonization of these scaffolds. Mainly stromal cells from bone marrow but also from adipose origin are used. Furthermore, osteoblasts, dental pulp cells, periodontal ligament cells, hESCs and iPSCs 
are used for colonization [107]. In addition, the differentiation and proliferation of the implemented cells is promoted by the addition of BMPs, fibroblast growth factors (FGFs) or VEGFs [108-111]. Of note, the osteogenic effects of, for instance, BMPs tend to diverge in animals compared to humans. This is suggested to be a result of the different expression pattern of transcription factors that additionally have different functions, especially when comparing MSCs from rodents and from humans [112]. Although VEGF is known to induce osteogenesis in vitro and in vivo in animal studies, no human clinical investigation on this has been performed for in vivo bone formation in humans [113]. Furthermore, biologics and biological compounds that are highly species-specific are becoming more important but fail to function in animals. These findings highlight the need to consider the biological inter-species difference and related specifications with regard to drug development. Thus, it is not surprising that human in vitro models in the field of bone regeneration are gaining more attention.

To generate scaffold-based artificial bone, scaffolds and bone cells are brought together and optionally combined with growth factors. Subsequently, the seeded cells are cultured in a 3D architecture either in non-perfused or perfused cultivation systems such as bioreactors, microfluidic devices. In this context, the scaffold supports cell adherence/attachment and thus migration and colonization and positively influences cell activation, differentiation and proliferation, thus acting as an osteogenic inducer [78]. To fulfill its orthopedic purpose as an implant, a suitable scaffold should have the following properties:

(i) Biocompatibility to promote cell adhesion and survival;

(ii) Appropriate scaffold architecture to initiate cell differentiation and proliferation;

(iii) Adequate mechanical properties to mimic the mechanical properties of the tissue of interest;

(iv) A bioactive material that allows interaction with the host tissue and has osteoinductive properties;

(v) Proper biodegradability [78,114-116].

Generally, scaffolds are used in orthopedic surgery as a temporary matrix for bone growth [117]. A wide range of materials can be considered to produce scaffolds. Due to the variety of materials and the improvement of manufacturing processes, the quality of research on the biological application of scaffolds has greatly improved in recent years. Sintered metal implants such as titanium or iron-magnesium scaffolds are strong and durable materials that exhibit superior biocompatibility and mechanical properties [118,119]. However, these implants are often not degradable or resorbable, and therefore remain as foreign bodies in the organism for the rest of their lives [116]. Interestingly, Lee and colleagues conducted a clinical trial with a magnesium alloy that proved to be fully biodegradable within one year, thereby supporting full regeneration of the bone defect [120]. One further development in the field of scaffold materials is the group of bioceramics. Bioceramics are often used in bone regeneration due to their osteoinductive capacity and ability to integrate cells such as MSCs into the scaffold. Commonly used materials, such as hydroxyapatite (HA) and tricalcium phosphate (TCP), show significant similarities to the mineral bone content and provide a suitable 3D scaffold architecture for implants [116,121]. In particular, HA is an almost perfect material due to its high biocompatibility, lack of cytotoxicity and controlled degradation properties [122]. However, brittleness and hardness of these materials are a concern with regard to adequate mechanical properties, which decrease in the course of their use [116]. Nevertheless, various approaches using ceramics have shown promising results in terms of bone regeneration in vitro and in vivo [123-125]. Scaffolds made of biodegradable polymers, both natural and synthetic, have recently attracted great interest in the field of BTE research and are considered ideal in terms of biocompatibility, durability, bioactive behavior, interaction with host tissue, low immunogenicity and biodegradability [116,117]. Hydrophilic, hydrogel-generating polymers such as gelatin or collagen demonstrating osteo-inductive properties are often used. Due to its natural occurrence in bone, cells easily attach to collagen and show their typical characteristics such as adherence and structural and functional properties, and collagen-based hydrogels reveal 
good remodeling and biodegradation properties [126-128]. In addition, other naturally occurring polymers such as alginate or silk used for BTE approaches have the advantage of easy processing $[129,130]$. However, synthetically produced polymers have the advantage over natural polymers in that they can be tailored to the specific requirements of the application through chemical modifications or molecular change [126]. As such, several polymers have been approved by the FDA, for instance, polycaprolactone (PCL) [131,132], poly (l-lactic acid) (PLLA) [133,134] or poly (ethylene glycol) (PEG), and are now in use [135]. Recently, bioglass was added to the extensive repertoire of bone scaffold materials [126]. Although scaffold-based approaches are already part of routine clinical practice, e.g., in the reconstruction of the jawbone after tooth extraction, these approaches have certain limitations in terms of modeling fracture healing processes. Most of these models focus on cell-scaffold interactions, biocompatibility and resorbability, thereby disregarding the finetuned mechanism of bone healing processes involving cell-cell and cell-matrix interactions. Thus, it is not surprising that the replication of in vivo processes such as morphological, biochemical and biomechanical features are mostly waived $[97,136]$. In addition, the generation of scaffolds that can either mimic the bone matrix for modeling fracture healing in vitro or be implanted into critical size defects to accelerate fracture gap bridging is focused primarily on cell colonization, biocompatibility and resorbability. While appropriate for implantation, this approach is limited for modeling fracture healing, because adequate diffusion of both oxygen and nutrients is restricted throughout the scaffold region above a certain size. This restriction based on diffusion limits results in heterogeneous cell colonization and thus distribution of cells on the corresponding scaffold $[97,102,137,138]$. In particular, non-porous scaffolds, which form a durable, dense and solid matrix, face the challenging conditions of low initial cell seeding numbers. Conversely, hydrogel-based approaches that allow homogeneous distribution of cells in larger cell numbers suffer from low durability and stability [102]. Natural biopolymers, on the other hand, have insufficiently resilient mechanical properties, show high batch-to-batch variability and behave in a potentially immunogenic manner, while synthetic scaffolds face the problem of undesirable acidic degradation [126]. In general, research on scaffold-based models focuses on the development and improvement of implants. The in vitro experiments for this are the precursor for the subsequent experiments in animals to finally find application in clinical practice. When using scaffold-based models as fracture healing models or bone models, vascularization is the main challenge in BTE. Above a certain size, tissue thickness limits nutrient and oxygen diffusion, which is required to support osteogenesis as well as osseointegration during bone healing and regeneration. Angiogenesis influences osteogenesis, with bone progenitor cells and osteoblasts located near vascular endothelial cells during new bone formation. In this regard, VEGF is the most important growth factor for vascular growth and is crucial for the effective coupling of angiogenesis and osteogenesis during bone healing and bone regeneration, respectively. Therefore, various strategies have been explored to develop a suitable vascular network in engineered scaffolds, such as (i) the use of biocompatible materials in scaffold design, (ii) micro-nano-structure, morphology and porosity, and roughness of scaffolds, (iii) ion-doped materials and (iv) the addition of angiogenic growth factors or recombinant proteins [139]. To address the limitation of insufficient vascularization, Ma and colleagues used an approach in which they incorporated magnesium particles into 3D-printed porous tantalum scaffolds via dopamine self-polymerization. Using this approach, they demonstrated improved osteogenic and angiogenic potential in vitro and improved osseointegration in vivo [140]. Xu et al. used an electrospun, fiber-porous PLLA/gelatin composite material doped with ceria nanoparticles that exhibited angiogenic properties in vivo, as demonstrated by the hen's egg chorioallantoic membrane test (HET-CAM) [141]. Quazi et al. demonstrated that bioactive ions released from bioglass formed a vascular network in an in vitro 2D tube formation assay using HUVEC cells [142]. These endeavors demonstrate the sophisticated strategies that are being used to significantly improve the inadequate vascularization of scaffold-based constructs and make them useful as in vitro models. 


\subsection{Scaffold-Free Model of Bone Regeneration}

Scaffold-free approaches exploit the ability of, for example, MSCs to self-organize and self-assemble. Spheroids are already frequently in use in order to mimic complex tissues such as brain, liver, solid tumors, cartilage and bone [143-146]. These models consist of self-assembled and self-organized cells and their ECM in a close cell-cell contact [147]. Once the conditions for self-assembly and self-organization are explored and established, handling and production becomes easy, offering the possibility for mid- to high-throughput approaches [78]. To date, a wide range of spheroid production methods have been developed, including folding of cell sheets, assembly of cells in hanging droplets, pelletization or centrifugation techniques to form micro- or mini-mass cultures, or the use of non-adhesive surfaces that lead to cell clumping [97]. In case of 3D bone tissue spheroid cultures, the osteogenic potential of MSC pellets is specifically enhanced $[148,149]$. The use of spheroid models mimics the in vivo situation better than 2D cultures due to their 3D architecture and has distinct advantages over scaffold-based approaches, e.g., no foreign or even exogenous materials are used, so challenging parameters such as biocompatibility and resorbability do not play a role. In addition, tissue formation is less time-consuming than in scaffold-based approaches due to the initially high cell density, eliminating the pitfalls of cell colonization involving cell proliferation and migration as decisive factors [102]. Since spheroids are very small items often based on micro- and mini-mass cultures and spatial or temporal changes on a superordinate tissue level are very challenging to obtain, we recently developed scaffold-free bone constructs on a macroscale-level using a combination of mesenchymal condensation and intermittent mechanical stimulation. This approach is based on the work of Ponomarev and colleagues, who introduced scaffold-free cartilage transplants only consisting of cells and their ECM, which showed distinct similarities to human cartilage [150]. We also used these models for studies on the cytokine-driven cellular and matrix-related changes during cartilage degradation [151] and as the cartilaginous part of a 3D osteochondral model which we established to mimic cytokine-induced features of arthritis in vitro [152]. The generation of scaffold-free bone-like constructs (SFBCs) was advanced by slightly adjusting the manufacturing protocol of the scaffold-free cartilage grafts and by adding osteogenic components during the maturation process toward endochondral ossification. With this approach, we achieved mineralization of the complete SFBCs without the typical formation of necrotic areas in the center of the constructs. Furthermore, by analyzing the expression of specific bone-related markers at the mRNA and protein levels, we were able to demonstrate the functionality of SFBCs based on the enhancement of the osteogenic potential of immune cells in an in vitro fracture hematoma, mimicking the initial phase of fracture healing [56,153]. The main advantage of such macroscale approaches compared to spheroids is the 3D architecture, low cell number, physiologically relevant size, matrix density and typical mechanical properties [151,153].

However, the lack of vascularization of spheroids above a critical size often leads to the formation of necrotic centers, which is a well-known problem of spheroidal cell cultures [154]. Above a critical spheroid size, cells of the center region face challenging conditions of a reduction in supply of oxygen and nutrients. Although cells, especially MSCs, are capable of adapting to a hypoxic microenvironment and insufficient nutrient supply by metabolic reprogramming, they are not able to cope with an anoxic microenvironment and the complete lack of nutrient supply. Reduction of physiological oxygen availability with sufficient supply of nutrients, e.g., glucose, seems to favor MSC survival and their differentiation towards the osteogenic lineage, while adipogenesis is reduced $[56,155,156]$. Conversely, hypoxia was also shown to inhibit osteogenesis in MSCs through direct regulation of RUNX2 and/or by activation of the Notch signaling pathway [157,158]. In addition, hypoxia was demonstrated to promote cell proliferation and limit cell differentiation of MG-63 osteoblasts $[159,160]$. Thus, the adaptation processes of osteogenic cells and their precursors is still a matter of research, and new insights could eventually lead to considerable improvements in terms of spheroidal bone tissue cultures. However, the more complex a tissue is, the less suitable it is for modeling using self-organized spheroids. Bone 
itself is composed of different structures including a variety of cell types. Therefore, only individual components are suitable for modeling with spheroids, such as the anabolic bone components including osteoblasts and osteocytes, while catabolic osteoclasts are difficult or impossible to include. This may explain why spheroids equivalent to human bone are still difficult to find. However, there are several approaches to overcome the problem of cell homogeneity by co-culturing arrangements using different cell types for spheroid formation.

A very recent approach to using different cell types in an organized manner combines scaffolds with scaffold-free spheroid models, using the latter as building blocks for tissue engineering of bone, thus combining the synergistic effects of both components in terms of osteo-differentiation and osteo-integration [102,161,162]. In this approach, the scaffold represents the ECM to which cell-containing spheroids adhere, into which the cells can migrate and thereby proliferate and differentiate. In addition, scaffolds must be designed to maintain and, at best, preserve spheroids in vitro and if needed in vivo for the purpose to regenerate injured tissue by promoting repair processes and vascularization $[163,164]$. Thus, morphogenesis is mimicked by the intrinsic capacity of spheroids to fuse to each other [161]. To merge with scaffolds, spheroids are most often combined with cage-like scaffolds of various materials. For instance, Sankar et al. used electrospun fiber mats in combination with MSC spheroids to obtain an enhanced osteogenic differentiation [162]. The essential bottom-up engineering strategy that enables the combination of scaffolds and spheroids in a highly coordinated and reproducible manner is 3D bioprinting. This technique not only allows the production of micro-scaffolds in almost any desired shape, but also the combination of cells and scaffolds [97]. Daly and colleagues used an inkjet-based bioprinting approach to seed MSCs and chondrocytes into 3D-printed micro-chambers, resulting in a cartilage construct similar to native cartilage [165].

Although 3D bioprinting is a promising technology and allows the generation of highly reproducible models in mid-throughput output, several challenges must be addressed. Since the biomaterials and spheroids have the same output requirements, these face the same limitations, as already discussed. Additionally, the implementation of vasculature to supply nutrient and oxygen to inner tissue structures is still elusive.

\subsection{Extending the Models of Bone Regeneration-From Inflammation to Perfusion}

Healthy bone is characterized by a distinct vascularization to supply and extract nutrients, oxygen, metabolites, growth factors and hormones from the bone. Therefore, vascularization plays an essential role in bone development, bone maturation, bone growth, bone regeneration and bone remodeling [166]. Several approaches have been attempted to implement vascularization within in vitro models of bone tissue. The endeavor is quite complex, which means that even for the approaches of in vitro modeling of angiogenic and osteogenic material, a living organism seems to be still needed. Zhang et al. developed a double-cell sheet complex in vitro, whereby the first cell sheet is composed of an osteogenic cell layer (osteogenic potential) and the second of vascular endothelial cells (blood vessel potential), transplanted to nude mice. After 12 weeks, they observed both osteogenic and blood vessel formation potential in vivo [103]. Thus, replacement of animal experiments for this approach is not yet achievable. As a real alternative approach to the still necessary use of animals at least as hosts for in vitro models, Chiesa et al. developed a vascularized in vitro bone model by employing $3 \mathrm{D}$ bioprinting. They combined pre-differentiated osteogenic MSCs and HUVECs on a gelatin-nanohydroxyapatite 3D bioprinted scaffold. After 4 weeks of cultivation, the HUVECs formed a tubular-like structure and a capillarylike network within the bone constructs, alongside ongoing osteogenesis [104].

To mimic the crosstalk between immune cells and bone during the initial phase of fracture healing, we added the immune component to bone cells and established a fracture hematoma model. In brief, we combined scaffold-free macroscale bone constructs (SFBCs) with a coagulant of human peripheral blood and MSCs and demonstrated the osteo-inductive potential of SFBCs on fracture hematoma, mimicking several key features 
of the initial phase after fracture in vitro [153]. Thus, the combination of cells and tissues in sophisticated in vitro models may be promising tools to unravel distinct fracture-healing processes in order to gain insights into human fracture healing and finally to improve human healthcare. To significantly improve the cultivation of both scaffold-based and scaffold-free constructs, dynamic bioreactor systems offer an attractive way to increase differentiation and proliferation of implemented cells via monitoring of metabolic parameters and controllable perfusion. These include, but are not limited to, perfusion bioreactors, spinner flasks, and systems with electromagnetic or mechanical stimulation properties, and allow adequate monitoring and control of various important properties such as physical, biological, or chemical parameters during the process of bone formation in vitro, as has been extensively reported by Rauh and colleagues [167].

\section{Conclusions}

The continuous formation and degradation by bone-forming osteoblasts and boneresorbing osteoclasts is a basic prerequisite for skeletal development during growth and for strength but also flexibility, corresponding to the stresses of everyday life, which comes about through the repair of stress-induced minute cracks in the bone. Due to constant bone remodeling, the entire skeleton is renewed every eight to ten years.

In healthy individuals, bone has the intrinsic ability to continually regenerate from fractures due to continuous bone remodeling. In the clinical setting, the most common form of bone regeneration is fracture healing, which recapitulates the progression of normal skeletal development.

Bone regeneration consists of a series of biological events of bone induction and conduction involving different cell types and signaling pathways in a defined temporal and spatial sequence to optimally repair bone and restore skeletal function. Bone fractures usually heal so well without complications that no scar remains. With increasing age and in the case of certain pre-existing conditions, such as rheumatism, diabetes mellitus or osteoporosis, as well as under certain therapies, bones break more quickly and/or heal more poorly or not at all, so that in the latter case one speaks of delayed, disturbed or incomplete bone healing.

Thus, fractures, fracture healing disorders and their consequences are of high interest from a socio-economic perspective and in medical healthcare. Given the burden of patients, the first medical responsibility is to:

(i) Identify and treat patients at-risk to prevent fractures;

(ii) Prevent, improve and accelerate inadequate fracture healing.

Thus, the foremost goal must be to identify markers and marker combinations for both of the aforementioned conditions, to verify these for a diagnostic tool and ultimately to develop corresponding therapy options using surrogate in vitro, ex vivo and in vivo models.

To date, a variety of animal models have been the gold standard for studying the complexity of bone healing in vivo at the systemic level of the whole organism. Although animal models are limited for the identification of diagnostic markers, they are surrogate models for human patients that provide the capability to test and verify new therapeutic approaches including e.g., medications and biomaterials for regenerative bone reconstruction or implants and fixation methods for appropriate surgical interventions. In the case of pharmaceutical intervention, animals still provide the sole option from a regulatory perspective to test and determine pharmacodynamics and pharmacokinetics in preclinical research.

Before a medicinal product with a new active compound can receive approval, it must undergo extensive testing for quality, safety and efficacy in a suitable animal or human cell model (in vitro) or organ model (ex vivo). However, the major challenge is the transition from animal testing to the first stage of human application, the so-called phase I of clinical testing. Here it is important to obtain data on the behavior of the active compound in the human body, which may differ from the data obtained in animal experiments. Facing this challenge, in vitro and ex vivo models (tissue explants) provide easy-to-handle tools to resolve isolated key aspects related to bone healing. These models involve bone tissue engi- 
neering strategies, which include scaffold-based and scaffold-free approaches and include micro fluidic devices, which provide the basis for more comprehensive, continuative model systems implementing different cell types or tissues including a vascularization. Thus, microfluidic devices ensure the permanent supply of nutrients and real-time monitoring of metabolites, $\mathrm{pH}$, temperature and oxygen concentrations. The extension of microfluidic devices to multi-chamber systems offers the possibility to combine two or more cell/tissue types or in vitro models under controlled and monitored conditions. Compared to conventional in vitro and in vivo bone models, microfluidic models or their miniaturization to chip level so-called organ-on-a-chip platforms in which organoids are cultured offer more biomimetic tissue culture conditions. In addition, the combination of a variety of organoids representing different tissues such as bone, skin, liver, kidney or heart offers the opportunity of searching for drug candidates or their initial screening with respect to mechanism and potency of action, affinity and specificity (pharmacodynamics studies) as well as absorption and metabolism (initial pharmacokinetics studies). Thus, the implementation of bone in a multi-organ-on-a-chip or even human-on-a-chip application would also offer the study of its fracture or its regeneration after fracture with increased predictive power for clinical assays, thus promoting new avenues in the study of fracture healing disorders.

However, the in vitro or ex vivo models discussed here cannot currently be a substitute for animal models, but rather would be an intermediate step that (i) could help collect data on the behavior of an agent in the human body that might differ from data obtained in animal studies, and thus (ii) would ultimately significantly reduce the number of animals that would otherwise have to be used.

Conclusively, the close connection but not the strict separation between in vivo and in vitro/ex vivo research is still of great importance to pave the way towards a better understanding and development of new therapies to foster existing therapeutic strategies, and not only in the treatment of bone healing disorders.

Author Contributions: Conceptualization, M.P., T.G.; writing-original draft preparation, M.P., A.D., A.L., F.B., P.H., T.G.; writing-review and editing, M.P., A.D., A.L., F.B., P.H., T.G.; visualization, A.D.; supervision, T.G.; project administration, T.G.; funding acquisition, T.G. All authors have read and agreed to the published version of the manuscript.

Funding: The work of T.G. was funded by the German Research Foundation (353142848, grant approval $07 / 2017$ ). A.L. is currently supported by the Joachim Herz Foundation (Add-on Fellowship 2019) and receives a DFG Research Fellowship (440525257, grant approval 01/2021). A.D. is gratefully supported by the Studienstiftung des deutschen Volkes and by the Joachim Herz Foundation (Add-on Fellowship 2020).

Institutional Review Board Statement: Not applicable.

Informed Consent Statement: Not applicable.

Data Availability Statement: Not applicable.

Acknowledgments: In this section, you can acknowledge any support given which is not covered by the author contribution or funding sections. This may include administrative and technical support, or donations in kind (e.g., materials used for experiments).

Conflicts of Interest: The authors declare no conflict of interest. The funders had no role in the writing of the manuscript, or in the decision to publish the manuscript.

\section{References}

1. Florencio-Silva, R.; Sasso, G.R.d.S.; Sasso-Cerri, E.; Simões, M.J.; Cerri, P.S. Biology of Bone Tissue: Structure, Function, and Factors That Influence Bone Cells. BioMed Res. Int. 2015, 2015, 421746. [CrossRef]

2. Tzelepi, V.; Tsamandas, A.C.; Zolota, V.; Scopa, C.D. Bone Anatomy, Physiology and Function. In Bone Metastases: A Translational and Clinical Approach; Kardamakis, D., Vassiliou, V., Chow, E., Eds.; Springer Netherlands: Dordrecht, The Netherlands, 2009; pp. 3-30.

3. Einhorn, T.A. The cell and molecular biology of fracture healing. Clin. Orthop. Relat. Res. 1998, S7-S21. [CrossRef] 
4. Cullinane, D.M. The role of osteocytes in bone regulation: Mineral homeostasis versus mechanoreception. J. Musculoskelet. Neuronal Interact. 2002, 2, 242-244.

5. Bonewald, L.F.; Johnson, M.L. Osteocytes, mechanosensing and Wnt signaling. Bone 2008, 42, 606-615. [CrossRef]

6. Rucci, N. Molecular biology of bone remodelling. Clin. Cases Min. Bone Metab. 2008, 5, 49-56.

7. Shapiro, F. Bone development and its relation to fracture repair. The role of mesenchymal osteoblasts and surface osteoblasts. Eur. Cells Mater. 2008, 15, 53-76. [CrossRef]

8. Olsen, B.R.; Reginato, A.M.; Wang, W.F. Bone development. Annu. Rev. Cell Dev. Biol. 2000, 16, 191-220. [CrossRef] [PubMed]

9. Mackie, E.J.; Ahmed, Y.A.; Tatarczuch, L.; Chen, K.S.; Mirams, M. Endochondral ossification: How cartilage is converted into bone in the developing skeleton. Int. J. Biochem. Cell Biol. 2008, 40, 46-62. [CrossRef] [PubMed]

10. Teti, A. Bone development: Overview of bone cells and signaling. Curr. Osteoporos. Rep. 2011, 9, 264-273. [CrossRef] [PubMed]

11. Marsell, R.; Einhorn, T.A. The biology of fracture healing. Injury 2011, 42, 551-555. [CrossRef] [PubMed]

12. Morgan, E.F.; De Giacomo, A.; Gerstenfeld, L.C. Overview of skeletal repair (fracture healing and its assessment). Methods Mol. Biol. 2014, 1130, 13-31. [CrossRef]

13. Annamalai, R.T.; Turner, P.A.; Carson, W.F.t.; Levi, B.; Kunkel, S.; Stegemann, J.P. Harnessing macrophage-mediated degradation of gelatin microspheres for spatiotemporal control of BMP2 release. Biomaterials 2018, 161, 216-227. [CrossRef] [PubMed]

14. Tian, L.; Tang, N.; Ngai, T.; Wu, C.; Ruan, Y.; Huang, L.; Qin, L. Hybrid fracture fixation systems developed for orthopaedic applications: A general review. J. Orthop. Transl. 2019, 16, 1-13. [CrossRef]

15. Kolar, P.; Gaber, T.; Perka, C.; Duda, G.N.; Buttgereit, F. Human early fracture hematoma is characterized by inflammation and hypoxia. Clin. Orthop. Relat. Res. 2011, 469, 3118-3126. [CrossRef] [PubMed]

16. Sheen, J.R.; Garla, V.V. Fracture Healing Overview. In StatPearls; StatPearls Publishing LLC.: Treasure Island, FL, USA, 2020.

17. Street, J.T.; Wang, J.H.; Wu, Q.D.; Wakai, A.; McGuinness, A.; Redmond, H.P. The angiogenic response to skeletal injury is preserved in the elderly. J. Orthop. Res. 2001, 19, 1057-1066. [CrossRef]

18. Stegen, S.; van Gastel, N.; Carmeliet, G. Bringing new life to damaged bone: The importance of angiogenesis in bone repair and regeneration. Bone 2015, 70, 19-27. [CrossRef]

19. Hankenson, K.D.; Dishowitz, M.; Gray, C.; Schenker, M. Angiogenesis in bone regeneration. Injury 2011, 42, 556-561. [CrossRef] [PubMed]

20. Grosso, A.; Burger, M.G.; Lunger, A.; Schaefer, D.J.; Banfi, A.; Di Maggio, N. It Takes Two to Tango: Coupling of Angiogenesis and Osteogenesis for Bone Regeneration. Front. Bioeng. Biotechnol. 2017, 5. [CrossRef]

21. Lu, C.; Miclau, T.; Hu, D.; Marcucio, R.S. Ischemia leads to delayed union during fracture healing: A mouse model. J. Orthop. Res. 2007, 25, 51-61. [CrossRef]

22. Brownlow, H.C.; Reed, A.; Simpson, A.H. The vascularity of atrophic non-unions. Injury 2002, 33, 145-150. [CrossRef]

23. Fazzalari, N.L. Bone fracture and bone fracture repair. Osteoporos. Int. 2011, 22, 2003-2006. [CrossRef]

24. McKenzie, J.A.; Silva, M.J. Comparing histological, vascular and molecular responses associated with woven and lamellar bone formation induced by mechanical loading in the rat ulna. Bone 2011, 48, 250-258. [CrossRef]

25. Einhorn, T.A.; Gerstenfeld, L.C. Fracture healing: Mechanisms and interventions. Nat. Rev. Rheumatol. 2015, 11, 45-54. [CrossRef] [PubMed]

26. Ghiasi, M.S.; Chen, J.; Vaziri, A.; Rodriguez, E.K.; Nazarian, A. Bone fracture healing in mechanobiological modeling: A review of principles and methods. Bone Rep. 2017, 6, 87-100. [CrossRef] [PubMed]

27. Cummings, S.R.; Eastell, R. Stop (mis)classifying fractures as high- or low-trauma or as fragility fractures. Osteoporos. Int. 2020, 31, 1023-1024. [CrossRef] [PubMed]

28. Leslie, W.D.; Schousboe, J.T.; Morin, S.N.; Martineau, P.; Lix, L.M.; Johansson, H.; McCloskey, E.V.; Harvey, N.C.; Kanis, J.A. Fracture risk following high-trauma versus non-trauma fracture: A registry-based cohort study. Osteoporos Int. 2020, in press. [CrossRef] [PubMed]

29. Mackey, D.C.; Black, D.M.; Bauer, D.C.; McCloskey, E.V.; Eastell, R.; Mesenbrink, P.; Thompson, J.R.; Cummings, S.R. Effects of antiresorptive treatment on nonvertebral fracture outcomes. J. Bone Min. Res. 2011, 26. [CrossRef] [PubMed]

30. Mackey, D.C.; Lui, L.Y.; Cawthon, P.M.; Bauer, D.C.; Nevitt, M.C.; Cauley, J.A.; Hillier, T.A.; Lewis, C.E.; Barrett-Connor, E.; Cummings, S.R. High-trauma fractures and low bone mineral density in older women and men. JAMA 2007, 298. [CrossRef]

31. Muschitz, C.; Kocijan, R.; Baierl, A.; Dormann, R.; Feichtinger, X.; Haschka, J.; Szivak, M.; Muschitz, G.K.; Schanda, J.; Pietschmann, P.; et al. Preceding and subsequent high- and low-trauma fracture patterns-a 13-year epidemiological study in females and males in Austria. Osteoporos. Int. 2017, 28. [CrossRef]

32. Pereira, L.; Bliuc, D.; Stanford, P.; Eisman, J.A.; Center, J.R. More-than-minimal-trauma fractures are associated with low bone density: An 8-year prospective study. Osteoporos. Int. 2017, 28. [CrossRef]

33. Sanders, K.M.; Pasco, J.A.; Ugoni, A.M.; Nicholson, G.C.; Seeman, E.; Martin, T.J.; Skoric, B.; Panahi, S.; Kotowicz, M.A. The exclusion of high trauma fractures may underestimate the prevalence of bone fragility fractures in the community: The Geelong Osteoporosis Study. J. Bone Min. Res. 1998, 13. [CrossRef] [PubMed]

34. Oden, A.; McCloskey, E.V.; Kanis, J.A.; Harvey, N.C.; Johansson, H. Burden of high fracture probability worldwide: Secular increases 2010-2040. Osteoporos. Int. 2015, 26, 2243-2248. [CrossRef] [PubMed] 
35. Kanis, J.A.; Cooper, C.; Rizzoli, R.; Abrahamsen, B.; Al-Daghri, N.M.; Brandi, M.L.; Cannata-Andia, J.; Cortet, B.; Dimai, H.P.; Ferrari, S.; et al. Identification and management of patients at increased risk of osteoporotic fracture: Outcomes of an ESCEO expert consensus meeting. Osteoporos. Int. 2017, 28, 2023-2034. [CrossRef]

36. McCloskey, E.; Rathi, J.; Heijmans, S.; Blagden, M.; Cortet, B.; Czerwinski, E.; Hadji, P.; Payer, J.; Palmer, K.; Stad, R.; et al. The osteoporosis treatment gap in patients at risk of fracture in European primary care: A multi-country cross-sectional observational study. Osteoporos. Int. 2021, 32, 251-259. [CrossRef] [PubMed]

37. Hernlund, E.; Svedbom, A.; Ivergard, M.; Compston, J.; Cooper, C.; Stenmark, J.; McCloskey, E.V.; Jonsson, B.; Kanis, J.A. Osteoporosis in the European Union: Medical management, epidemiology and economic burden. A report prepared in collaboration with the International Osteoporosis Foundation (IOF) and the European Federation of Pharmaceutical Industry Associations (EFPIA). Arch. Osteoporos. 2013, 8, 136. [CrossRef]

38. O'Hanlon, C.E.; Parthan, A.; Kruse, M.; Cartier, S.; Stollenwerk, B.; Jiang, Y.; Caloyeras, J.P.; Crittenden, D.B.; Barron, R. A Model for Assessing the Clinical and Economic Benefits of Bone-forming Agents for Reducing Fractures in Postmenopausal Women at High, Near-term Risk of Osteoporotic Fracture. Clin. Ther. 2017, 39, 1276-1290. [CrossRef]

39. van Geel, T.A.; van Helden, S.; Geusens, P.P.; Winkens, B.; Dinant, G.J. Clinical subsequent fractures cluster in time after first fractures. Ann. Rheum. Dis. 2009, 68, 99-102. [CrossRef]

40. Tafaro, L.; Napoli, N. Current and Emerging Treatment of Osteoporosis. In Orthogeriatrics: The Management of Older Patients with Fragility Fractures; Falaschi, P., Marsh, D., Eds.; Springer: Cham, Switzerland, 2021; pp. 257-272.

41. Falaschi, P.; Marques, A.; Giordano, S. Osteoporosis and Fragility in Elderly Patients. In Orthogeriatrics: The Management of Older Patients with Fragility Fractures; Falaschi, P., Marsh, D., Eds.; Springer: Cham, Switzerland, 2021; pp. 35-52.

42. Chen, L.R.; Ko, N.Y.; Chen, K.H. Medical Treatment for Osteoporosis: From Molecular to Clinical Opinions. Int. J. Mol. Sci. 2019, 20, 2213. [CrossRef] [PubMed]

43. Compston, J.E.; McClung, M.R.; Leslie, W.D. Osteoporosis. Lancet 2019, 393, 364-376. [CrossRef]

44. Singer, A.; Exuzides, A.; Spangler, L.; O’Malley, C.; Colby, C.; Johnston, K.; Agodoa, I.; Baker, J.; Kagan, R. Burden of illness for osteoporotic fractures compared with other serious diseases among postmenopausal women in the United States. Mayo Clin. Proc. 2015, 90, 53-62. [CrossRef]

45. Truelsen, T.; Piechowski-Jozwiak, B.; Bonita, R.; Mathers, C.; Bogousslavsky, J.; Boysen, G. Stroke incidence and prevalence in Europe: A review of available data. Eur. J. Neurol. 2006, 13, 581-598. [CrossRef]

46. Hoff, P.; Gaber, T.; Strehl, C.; Jakstadt, M.; Hoff, H.; Schmidt-Bleek, K.; Lang, A.; Rohner, E.; Huscher, D.; Matziolis, G.; et al. A Pronounced Inflammatory Activity Characterizes the Early Fracture Healing Phase in Immunologically Restricted Patients. Int. J. Mol. Sci. 2017, 18, 583. [CrossRef] [PubMed]

47. Bogoch, E.R.; Moran, E.L. Bone abnormalities in the surgical treatment of patients with rheumatoid arthritis. Clin. Orthop. Relat. Res. 1999, 8-21. [CrossRef] [PubMed]

48. Dominiak, B.; Oxberry, W.; Chen, P. Study on a nonhealing fracture from a patient with systemic lupus erythematosus and its pathogenetic mechanisms. Ultrastruct. Pathol. 2005, 29, 107-120. [CrossRef]

49. Follak, N.; Kloting, I.; Merk, H. Influence of diabetic metabolic state on fracture healing in spontaneously diabetic rats. Diabetes Metab. Res. Rev 2005, 21, 288-296. [CrossRef] [PubMed]

50. Kidder, L.S.; Chen, X.; Schmidt, A.H.; Lew, W.D. Osteogenic protein-1 overcomes inhibition of fracture healing in the diabetic rat: A pilot study. Clin. Orthop. Relat. Res. 2009, 467, 3249-3256. [CrossRef] [PubMed]

51. Stromqvist, B. Hip fracture in rheumatoid arthritis. Acta Orthop. Scand. 1984, 55, 624-628. [CrossRef]

52. Tyndall, W.A.; Beam, H.A.; Zarro, C.; O'Connor, J.P.; Lin, S.S. Decreased platelet derived growth factor expression during fracture healing in diabetic animals. Clin. Orthop. Relat. Res. 2003, 319-330. [CrossRef]

53. Busti, A.J.; Hooper, J.S.; Amaya, C.J.; Kazi, S. Effects of perioperative antiinflammatory and immunomodulating therapy on surgical wound healing. Pharmacotherapy 2005, 25, 1566-1591. [CrossRef] [PubMed]

54. Van Lieshout, E.M.M.; Den Hartog, D. Effect of platelet-rich plasma on fracture healing. Injury 2020. [CrossRef]

55. Thomas, J.D.; Kehoe, J.L. Bone Nonunion. In StatPearls; StatPearls Publishing LLC.: Treasure Island, FL, USA, 2021.

56. Pfeiffenberger, M.; Hoff, P.; Thone-Reineke, C.; Buttgereit, F.; Lang, A.; Gaber, T. The in vitro human fracture hematoma model-A tool for preclinical drug testing. ALTEX 2020, 37, 561-578. [CrossRef] [PubMed]

57. Pfeiffenberger, M.; Bartsch, J.; Hoff, P.; Ponomarev, I.; Barnewitz, D.; Thöne-Reineke, C.; Buttgereit, F.; Gaber, T.; Lang, A. Hypoxia and mesenchymal stromal cells as key drivers of initial fracture healing in an equine in vitro fracture hematoma model. PLoS ONE 2019, 14, e0214276. [CrossRef] [PubMed]

58. Hoff, P.; Maschmeyer, P.; Gaber, T.; Schutze, T.; Raue, T.; Schmidt-Bleek, K.; Dziurla, R.; Schellmann, S.; Lohanatha, F.L.; Rohner, E.; et al. Human immune cells' behavior and survival under bioenergetically restricted conditions in an in vitro fracture hematoma model. Cell. Mol. Immunol. 2013, 10, 151-158. [CrossRef] [PubMed]

59. Pritzker, K.P. Animal models for osteoarthritis: Processes, problems and prospects. Ann. Rheum. Dis. 1994, 53, 406-420. [CrossRef] [PubMed]

60. Lang, A.; Schulz, A.; Ellinghaus, A.; Schmidt-Bleek, K. Osteotomy models - the current status on pain scoring and management in small rodents. Lab. Anim. 2016, 50, 433-441. [CrossRef] [PubMed]

61. O'Loughlin, P.F.; Morr, S.; Bogunovic, L.; Kim, A.D.; Park, B.; Lane, J.M. Selection and development of preclinical models in fracture-healing research. J. Bone Jt. Surg. Am. 2008, 90 (Suppl. 1), 79-84. [CrossRef] 
62. Garcia, P.; Histing, T.; Holstein, J.H.; Klein, M.; Laschke, M.W.; Matthys, R.; Ignatius, A.; Wildemann, B.; Lienau, J.; Peters, A.; et al. Rodent animal models of delayed bone healing and non-union formation: A comprehensive review. Eur. Cell Mater. 2013, 26, 1-12; discussion 12-14. [CrossRef]

63. Dumont, C.; Kauer, F.; Bohr, S.; Schmidtmann, U.; Knopp, W.; Engelhardt, T.; Stürmer, E.K.; Stürmer, K.M. Long-term effects of saw osteotomy versus random fracturing on bone healing and remodeling in a sheep tibia model. J. Orthop. Res. 2009, 27, 680-686. [CrossRef]

64. Klein, M.; Stieger, A.; Stenger, D.; Scheuer, C.; Holstein, J.H.; Pohlemann, T.; Menger, M.D.; Histing, T. Comparison of healing process in open osteotomy model and open fracture model: Delayed healing of osteotomies after intramedullary screw fixation. $J$. Orthop. Res. 2015, 33, 971-978. [CrossRef]

65. Haffner-Luntzer, M.; Hankenson, K.D.; Ignatius, A.; Pfeifer, R.; Khader, B.A.; Hildebrand, F.; van Griensven, M.; Pape, H.-C.; Lehmicke, M. Review of Animal Models of Comorbidities in Fracture-Healing Research. J. Orthop. Res. 2019, 37, $2491-2498$. [CrossRef]

66. Bucher, C.H.; Schlundt, C.; Wulsten, D.; Sass, F.A.; Wendler, S.; Ellinghaus, A.; Thiele, T.; Seemann, R.; Willie, B.M.; Volk, H.-D.; et al. Experience in the Adaptive Immunity Impacts Bone Homeostasis, Remodeling, and Healing. Front. Immunol. 2019, 10, 797. [CrossRef] [PubMed]

67. Haffner-Luntzer, M.; Kovtun, A.; Rapp, A.E.; Ignatius, A. Mouse Models in Bone Fracture Healing Research. Curr. Mol. Biol. Rep. 2016, 2, 101-111. [CrossRef]

68. Decker, S.; Reifenrath, J.; Omar, M.; Krettek, C.; Müller, C.W. Non-osteotomy and osteotomy large animal fracture models in orthopedic trauma research. Orthop. Rev. 2014, 6, 5575. [CrossRef] [PubMed]

69. Bigham-Sadegh, A.; Oryan, A. Selection of animal models for pre-clinical strategies in evaluating the fracture healing, bone graft substitutes and bone tissue regeneration and engineering. Connect Tissue Res. 2015, 56, 175-194. [CrossRef] [PubMed]

70. Gomes, P.S.; Fernandes, M.H. Rodent models in bone-related research: The relevance of calvarial defects in the assessment of bone regeneration strategies. Lab. Anim. 2011, 45, 14-24. [CrossRef] [PubMed]

71. Peric, M.; Dumic-Cule, I.; Grcevic, D.; Matijasic, M.; Verbanac, D.; Paul, R.; Grgurevic, L.; Trkulja, V.; Bagi, C.M.; Vukicevic, S. The rational use of animal models in the evaluation of novel bone regenerative therapies. Bone 2015, 70, 73-86. [CrossRef] [PubMed]

72. Aerssens, J.; Boonen, S.; Lowet, G.; Dequeker, J. Interspecies Differences in Bone Composition, Density, and Quality: Potential Implications for in Vivo Bone Research*. Endocrinology 1998, 139, 663-670. [CrossRef] [PubMed]

73. Pearce, A.I.; Richards, R.G.; Milz, S.; Schneider, E.; Pearce, S.G. Animal models for implant biomaterial research in bone: A review. Eur. Cell Mater. 2007, 13, 1-10. [CrossRef]

74. Muschler, G.F.; Raut, V.P.; Patterson, T.E.; Wenke, J.C.; Hollinger, J.O. The Design and Use of Animal Models for Translational Research in Bone Tissue Engineering and Regenerative Medicine. Tissue Eng. Part B Rev. 2009, 16, 123-145. [CrossRef] [PubMed]

75. Publications Office of the EU: Report from the Commission to the European Parliament and the Council 2019 Report on the Statistics on the Use of Animals for Scientific Purposes in the Member States of the European Union in 2015-2017; Directorate-General for Environment (European Commission), European Commission: Brussels, Belgium, 2020. Available online: https:/ /op.europa.eu/ en/publication-detail/- / publication/04a890d4-47ff-11ea-b81b-01aa75ed71a1 (accessed on 28 June 2021).

76. Busquet, F.; Kleensang, A.; Rovida, C.; Herrmann, K.; Leist, M.; Hartung, T. New European Union statistics on laboratory animal use-What really counts! Altex 2020, 37, 167-186. [CrossRef]

77. Weinstein, S.I.; Yelin, E.H.; Watkins-Castillo, S.I. Funding. Available online: https://www.boneandjointburden.org/fourthedition/ia0/funding (accessed on 28 June 2021).

78. Scheinpflug, J.; Pfeiffenberger, M.; Damerau, A.; Schwarz, F.; Textor, M.; Lang, A.; Schulze, F. Journey into Bone Models: A Review. Genes 2018, 9, 247. [CrossRef]

79. Cramer, E.E.A.; Ito, K.; Hofmann, S. Ex vivo Bone Models and Their Potential in Preclinical Evaluation. Curr. Osteoporos. Rep. 2021. [CrossRef]

80. Hunter, G.; Dickinson, J.; Herb, B.; Graham, R. Creation of Oxidized Zirconium Ortliopaedic Implants; Zardiackas, L.D., Freese, H.L., Kraay, M.J., Eds.; ASTM International: West Conshohocken, PA, USA, 2006; pp. 16-29.

81. Staiger, M.P.; Pietak, A.M.; Huadmai, J.; Dias, G. Magnesium and its alloys as orthopedic biomaterials: A review. Biomaterials 2006, 27, 1728-1734. [CrossRef]

82. Hojo, M.; Inokuchi, S.; Kidokoro, M.; Fukuyama, N.; Tanaka, E.; Tsuji, C.; Miyasaka, M.; Tanino, R.; Nakazawa, H. Induction of vascular endothelial growth factor by fibrin as a dermal substrate for cultured skin substitute. Plast. Reconstr. Surg. 2003, 111, 1638-1645. [CrossRef]

83. Ueda, H.; Hong, L.; Yamamoto, M.; Shigeno, K.; Inoue, M.; Toba, T.; Yoshitani, M.; Nakamura, T.; Tabata, Y.; Shimizu, Y. Use of collagen sponge incorporating transforming growth factor-beta1 to promote bone repair in skull defects in rabbits. Biomaterials 2002, 23, 1003-1010. [CrossRef]

84. Rezania, A.; Healy, K.E. The effect of peptide surface density on mineralization of a matrix deposited by osteogenic cells. $J$. Biomed. Mater. Res. 2000, 52, 595-600. [CrossRef]

85. Kasoju, N.; Bora, U. Silk Fibroin in Tissue Engineering. Adv. Healthc. Mater. 2012, 1, 393-412. [CrossRef]

86. Liu, L.S.; Thompson, A.Y.; Heidaran, M.A.; Poser, J.W.; Spiro, R.C. An osteoconductive collagen/hyaluronate matrix for bone regeneration. Biomaterials 1999, 20, 1097-1108. [CrossRef] 
87. Gomes, M.E.; Ribeiro, A.S.; Malafaya, P.B.; Reis, R.L.; Cunha, A.M. A new approach based on injection moulding to produce biodegradable starch-based polymeric scaffolds: Morphology, mechanical and degradation behaviour. Biomaterials 2001, 22, 883-889. [CrossRef]

88. Ishaug-Riley, S.L.; Crane, G.M.; Gurlek, A.; Miller, M.J.; Yasko, A.W.; Yaszemski, M.J.; Mikos, A.G. Ectopic bone formation by marrow stromal osteoblast transplantation using poly(DL-lactic-co-glycolic acid) foams implanted into the rat mesentery. $J$. Biomed. Mater. Res. 1997, 36, 1-8. [CrossRef]

89. Chen, L.J.; Wang, M. Production and evaluation of biodegradable composites based on PHB-PHV copolymer. Biomaterials 2002, 23, 2631-2639. [CrossRef]

90. Yaszemski, M.J.; Payne, R.G.; Hayes, W.C.; Langer, R.; Mikos, A.G. Evolution of bone transplantation: Molecular, cellular and tissue strategies to engineer human bone. Biomaterials 1996, 17, 175-185. [CrossRef]

91. Hu, Y.; Grainger, D.W.; Winn, S.R.; Hollinger, J.O. Fabrication of poly( $\alpha$-hydroxy acid) foam scaffolds using multiple solvent systems. J. Biomed. Mater. Res. 2002, 59, 563-572. [CrossRef] [PubMed]

92. Sheikh, F.A.; Ju, H.W.; Moon, B.M.; Lee, O.J.; Kim, J.-H.; Park, H.J.; Kim, D.W.; Kim, D.-K.; Jang, J.E.; Khang, G.; et al. Hybrid scaffolds based on PLGA and silk for bone tissue engineering. J. Tissue Eng. Regen. Med. 2016, 10, 209-221. [CrossRef] [PubMed]

93. Yao, Q.; Cosme, J.G.; Xu, T.; Miszuk, J.M.; Picciani, P.H.; Fong, H.; Sun, H. Three dimensional electrospun PCL/PLA blend nanofibrous scaffolds with significantly improved stem cells osteogenic differentiation and cranial bone formation. Biomaterials 2017, 115, 115-127. [CrossRef] [PubMed]

94. Bose, S.; Tarafder, S. Calcium phosphate ceramic systems in growth factor and drug delivery for bone tissue engineering: A review. Acta Biomater. 2012, 8, 1401-1421. [CrossRef]

95. Matsuno, T.; Hashimoto, Y.; Adachi, S.; Omata, K.; Yoshitaka, Y.; Ozeki, Y.; Umezu, Y.; Tabata, Y.; Nakamura, M.; Satoh, T. Preparation of injectable 3D-formed beta-tricalcium phosphate bead/alginate composite for bone tissue engineering. Dent. Mater. J. 2008, 27, 827-834. [CrossRef] [PubMed]

96. Jones, J.R. Review of bioactive glass: From Hench to hybrids. Acta Biomater. 2013, 9, 4457-4486. [CrossRef] [PubMed]

97. Kronemberger, G.S.; Matsui, R.A.M.; Miranda, G.d.A.S.d.C.E.; Granjeiro, J.M.; Baptista, L.S. Cartilage and bone tissue engineering using adipose stromal/stem cells spheroids as building blocks. World J. Stem Cells 2020, 12, 110-122. [CrossRef] [PubMed]

98. Shen, F.H.; Werner, B.C.; Liang, H.; Shang, H.; Yang, N.; Li, X.; Shimer, A.L.; Balian, G.; Katz, A.J. Implications of adipose-derived stromal cells in a 3D culture system for osteogenic differentiation: An in vitro and in vivo investigation. Spine J. 2013, 13, 32-43. [CrossRef] [PubMed]

99. Laschke, M.W.; Schank, T.E.; Scheuer, C.; Kleer, S.; Shadmanov, T.; Eglin, D.; Alini, M.; Menger, M.D. In vitro osteogenic differentiation of adipose-derived mesenchymal stem cell spheroids impairs their in vivo vascularization capacity inside implanted porous polyurethane scaffolds. Acta Biomater. 2014, 10, 4226-4235. [CrossRef]

100. Murata, D.; Tokunaga, S.; Tamura, T.; Kawaguchi, H.; Miyoshi, N.; Fujiki, M.; Nakayama, K.; Misumi, K. A preliminary study of osteochondral regeneration using a scaffold-free three-dimensional construct of porcine adipose tissue-derived mesenchymal stem cells. J. Orthop. Surg. Res. 2015, 10, 35. [CrossRef] [PubMed]

101. Fennema, E.M.; Tchang, L.A.H.; Yuan, H.; van Blitterswijk, C.A.; Martin, I.; Scherberich, A.; de Boer, J. Ectopic bone formation by aggregated mesenchymal stem cells from bone marrow and adipose tissue: A comparative study. J. Tissue Eng. Regen. Med. 2018, 12, e150-e158. [CrossRef] [PubMed]

102. Ovsianikov, A.; Khademhosseini, A.; Mironov, V. The Synergy of Scaffold-Based and Scaffold-Free Tissue Engineering Strategies. Trends Biotechnol. 2018, 36, 348-357. [CrossRef] [PubMed]

103. Zhang, H.; Zhou, Y.; Zhang, W.; Wang, K.; Xu, L.; Ma, H.; Deng, Y. Construction of vascularized tissue-engineered bone with a double-cell sheet complex. Acta Biomater. 2018, 77, 212-227. [CrossRef] [PubMed]

104. Chiesa, I.; De Maria, C.; Lapomarda, A.; Fortunato, G.M.; Montemurro, F.; Di Gesù, R.; Tuan, R.S.; Vozzi, G.; Gottardi, R. Endothelial cells support osteogenesis in an in vitro vascularized bone model developed by 3D bioprinting. Biofabrication 2020, 12, 025013. [CrossRef] [PubMed]

105. Amini, A.R.; Laurencin, C.T.; Nukavarapu, S.P. Bone tissue engineering: Recent advances and challenges. Crit. Rev. Biomed. Eng. 2012, 40, 363-408. [CrossRef]

106. Curry, A.S.; Pensa, N.W.; Barlow, A.M.; Bellis, S.L. Taking cues from the extracellular matrix to design bone-mimetic regenerative scaffolds. Matrix Biol. 2016, 52-54, 397-412. [CrossRef] [PubMed]

107. Robey, P.G. Cell sources for bone regeneration: The good, the bad, and the ugly (but promising). Tissue Eng. Part B Rev. 2011, 17, 423-430. [CrossRef] [PubMed]

108. Thompson, M.S.; Epari, D.R.; Bieler, F.; Duda, G.N. In vitro models for bone mechanobiology: Applications in bone regeneration and tissue engineering. Proc. Inst. Mech. Eng. Part H J. Eng. Med. 2010, 224, 1533-1541. [CrossRef]

109. Yin, J.; Qiu, S.; Shi, B.; Xu, X.; Zhao, Y.; Gao, J.; Zhao, S.; Min, S. Controlled release of FGF-2 and BMP-2 in tissue engineered periosteum promotes bone repair in rats. Biomed. Mater. 2018, 13, 025001. [CrossRef]

110. Kent Leach, J.; Kaigler, D.; Wang, Z.; Krebsbach, P.H.; Mooney, D.J. Coating of VEGF-releasing scaffolds with bioactive glass for angiogenesis and bone regeneration. Biomaterials 2006, 27, 3249-3255. [CrossRef] [PubMed]

111. De Witte, T.-M.; Fratila-Apachitei, L.E.; Zadpoor, A.A.; Peppas, N.A. Bone tissue engineering via growth factor delivery: From scaffolds to complex matrices. Regen. Biomater. 2018, 5, 197-211. [CrossRef] 
112. Osyczka, A.M.; Diefenderfer, D.L.; Bhargave, G.; Leboy, P.S. Different effects of BMP-2 on marrow stromal cells from human and rat bone. Cells Tissues Organs 2004, 176, 109-119. [CrossRef]

113. Dreyer, C.H.; Kjaergaard, K.; Ding, M.; Qin, L. Vascular endothelial growth factor for in vivo bone formation: A systematic review. J. Orthop. Transl. 2020, 24, 46-57. [CrossRef]

114. Stevens, B.; Yang, Y.; Mohandas, A.; Stucker, B.; Nguyen, K.T. A review of materials, fabrication methods, and strategies used to enhance bone regeneration in engineered bone tissues. J. Biomed. Mater Res. B Appl. Biomater. 2008, 85, 573-582. [CrossRef] [PubMed]

115. Muschler, G.F.; Nakamoto, C.; Griffith, L.G. Engineering principles of clinical cell-based tissue engineering. J. Bone Jt. Surg. Am. 2004, 86, 1541-1558. [CrossRef]

116. Turnbull, G.; Clarke, J.; Picard, F.; Riches, P.; Jia, L.; Han, F.; Li, B.; Shu, W. 3D bioactive composite scaffolds for bone tissue engineering. Bioact. Mater. 2018, 3, 278-314. [CrossRef] [PubMed]

117. Salgado, A.J.; Coutinho, O.P.; Reis, R.L. Bone Tissue Engineering: State of the Art and Future Trends. Macromol. Biosci. 2004, 4, 743-765. [CrossRef] [PubMed]

118. Chen, H.; Wang, C.; Zhu, X.; Zhang, K.; Fan, Y.; Zhang, X. Fabrication of porous titanium scaffolds by stack sintering of microporous titanium spheres produced with centrifugal granulation technology. Mater. Sci. Eng. C 2014, 43, 182-188. [CrossRef] [PubMed]

119. Chou, D.-T.; Wells, D.; Hong, D.; Lee, B.; Kuhn, H.; Kumta, P.N. Novel processing of iron-manganese alloy-based biomaterials by inkjet 3-D printing. Acta Biomater. 2013, 9, 8593-8603. [CrossRef] [PubMed]

120. Lee, J.-W.; Han, H.-S.; Han, K.-J.; Park, J.; Jeon, H.; Ok, M.-R.; Seok, H.-K.; Ahn, J.-P.; Lee, K.E.; Lee, D.-H.; et al. Long-term clinical study and multiscale analysis of in vivo biodegradation mechanism of Mg alloy. Proc. Natl. Acad. Sci. USA 2016, 113, 716-721. [CrossRef] [PubMed]

121. Wubneh, A.; Tsekoura, E.K.; Ayranci, C.; Uludağ, H. Current state of fabrication technologies and materials for bone tissue engineering. Acta Biomater. 2018, 80, 1-30. [CrossRef] [PubMed]

122. Ko, C.-L.; Chen, W.-C.; Chen, J.-C.; Wang, Y.-H.; Shih, C.-J.; Tyan, Y.-C.; Hung, C.-C.; Wang, J.-C. Properties of osteoconductive biomaterials: Calcium phosphate cement with different ratios of platelet-rich plasma as identifiers. Mater. Sci. Eng. C 2013, 33, 3537-3544. [CrossRef] [PubMed]

123. Baksh, D.; Davies, J.E.; Kim, S. Three-dimensional matrices of calcium polyphosphates support bone growth in vitro and in vivo. J. Mater. Sci. Mater. Med. 1998, 9, 743-748. [CrossRef]

124. Grynpas, M.D.; Pilliar, R.M.; Kandel, R.A.; Renlund, R.; Filiaggi, M.; Dumitriu, M. Porous calcium polyphosphate scaffolds for bone substitute applications in vivo studies. Biomaterials 2002, 23, 2063-2070. [CrossRef]

125. Marra, K.G.; Szem, J.W.; Kumta, P.N.; DiMilla, P.A.; Weiss, L.E. In vitro analysis of biodegradable polymer blend/hydroxyapatite composites for bone tissue engineering. J. Biomed. Mater. Res. 1999, 47, 324-335. [CrossRef]

126. Koons, G.L.; Diba, M.; Mikos, A.G. Materials design for bone-tissue engineering. Nat. Rev. Mater. 2020, 5, 584-603. [CrossRef]

127. Chang, S.-W.; Buehler, M.J. Molecular biomechanics of collagen molecules. Mater. Today 2014, 17, 70-76. [CrossRef]

128. Neffe, A.T.; Pierce, B.F.; Tronci, G.; Ma, N.; Pittermann, E.; Gebauer, T.; Frank, O.; Schossig, M.; Xu, X.; Willie, B.M.; et al. One Step Creation of Multifunctional 3D Architectured Hydrogels Inducing Bone Regeneration. Adv. Mater. 2015, 27, 1738-1744. [CrossRef]

129. Luo, Z.; Zhang, S.; Pan, J.; Shi, R.; Liu, H.; Lyu, Y.; Han, X.; Li, Y.; Yang, Y.; Xu, Z.; et al. Time-responsive osteogenic niche of stem cells: A sequentially triggered, dual-peptide loaded, alginate hybrid system for promoting cell activity and osteo-differentiation. Biomaterials 2018, 163, 25-42. [CrossRef] [PubMed]

130. Shi, L.; Wang, F.; Zhu, W.; Xu, Z.; Fuchs, S.; Hilborn, J.; Zhu, L.; Ma, Q.; Wang, Y.; Weng, X.; et al. Self-Healing Silk Fibroin-Based Hydrogel for Bone Regeneration: Dynamic Metal-Ligand Self-Assembly Approach. Adv. Funct. Mater. 2017, $27,1700591$. [CrossRef]

131. Li, L.; Li, J.; Guo, J.; Zhang, H.; Zhang, X.; Yin, C.; Wang, L.; Zhu, Y.; Yao, Q. 3D Molecularly Functionalized Cell-Free Biomimetic Scaffolds for Osteochondral Regeneration. Adv. Funct. Mater. 2019, 29, 1807356. [CrossRef]

132. Hasani-Sadrabadi, M.M.; Sarrion, P.; Nakatsuka, N.; Young, T.D.; Taghdiri, N.; Ansari, S.; Aghaloo, T.; Li, S.; Khademhosseini, A.; Weiss, P.S.; et al. Hierarchically Patterned Polydopamine-Containing Membranes for Periodontal Tissue Engineering. ACS Nano 2019, 13, 3830-3838. [CrossRef] [PubMed]

133. Zhang, S.; Ma, B.; Liu, F.; Duan, J.; Wang, S.; Qiu, J.; Li, D.; Sang, Y.; Liu, C.; Liu, D.; et al. Polylactic Acid Nanopillar Array-Driven Osteogenic Differentiation of Human Adipose-Derived Stem Cells Determined by Pillar Diameter. Nano Lett. 2018, 18, $2243-2253$. [CrossRef] [PubMed]

134. Kirillova, A.; Kelly, C.; von Windheim, N.; Gall, K. Bioinspired Mineral-Organic Bioresorbable Bone Adhesive. Adv. Healthc. Mater. 2018, 7, 1800467. [CrossRef]

135. Johnson, C.T.; Wroe, J.A.; Agarwal, R.; Martin, K.E.; Guldberg, R.E.; Donlan, R.M.; Westblade, L.F.; García, A.J. Hydrogel delivery of lysostaphin eliminates orthopedic implant infection by Staphylococcus aureus and supports fracture healing. Proc. Natl. Acad. Sci. USA 2018, 115, E4960-E4969. [CrossRef]

136. Laschke, M.W.; Menger, M.D. Life is 3D: Boosting Spheroid Function for Tissue Engineering. Trends Biotechnol. 2017, 35, 133-144. [CrossRef] [PubMed] 
137. Guduric, V.; Metz, C.; Siadous, R.; Bareille, R.; Levato, R.; Engel, E.; Fricain, J.C.; Devillard, R.; Luzanin, O.; Catros, S. Layer-bylayer bioassembly of cellularized polylactic acid porous membranes for bone tissue engineering. J. Mater. Sci. Mater. Med. 2017, 28, 78. [CrossRef]

138. Forrestal, D.P.; Klein, T.J.; Woodruff, M.A. Challenges in engineering large customized bone constructs. Biotechnol. Bioeng. 2017, 114, 1129-1139. [CrossRef]

139. Collins, M.N.; Ren, G.; Young, K.; Pina, S.; Reis, R.L.; Oliveira, J.M. Scaffold Fabrication Technologies and Structure/Function Properties in Bone Tissue Engineering. Adv. Funct. Mater. 2021, 31, 2010609. [CrossRef]

140. Ma, L.; Cheng, S.; Ji, X.; Zhou, Y.; Zhang, Y.; Li, Q.; Tan, C.; Peng, F.; Zhang, Y.; Huang, W. Immobilizing magnesium ions on 3D printed porous tantalum scaffolds with polydopamine for improved vascularization and osteogenesis. Mater. Sci. Eng. C 2020, 117, 111303. [CrossRef]

141. Xu, Z.; Xu, Y.; Basuthakur, P.; Patra, C.R.; Ramakrishna, S.; Liu, Y.; Thomas, V.; Nanda, H.S. Fibro-porous PLLA/gelatin composite membrane doped with cerium oxide nanoparticles as bioactive scaffolds for future angiogenesis. J. Mater. Chem. B 2020, 8 , 9110-9120. [CrossRef]

142. Qazi, T.H.; Berkmann, J.C.; Schoon, J.; Geißler, S.; Duda, G.N.; Boccaccini, A.R.; Lippens, E. Dosage and composition of bioactive glasses differentially regulate angiogenic and osteogenic response of human MSCs. J. Biomed. Mater. Res. Part A 2018, 106, 2827-2837. [CrossRef]

143. Wu, F.J.; Friend, J.R.; Hsiao, C.C.; Zilliox, M.J.; Ko, W.J.; Cerra, F.B.; Hu, W.S. Efficient assembly of rat hepatocyte spheroids for tissue engineering applications. Biotechnol. Bioeng. 1996, 50, 404-415. [CrossRef]

144. Kelm, J.M.; Timmins, N.E.; Brown, C.J.; Fussenegger, M.; Nielsen, L.K. Method for generation of homogeneous multicellular tumor spheroids applicable to a wide variety of cell types. Biotechnol. Bioeng. 2003, 83, 173-180. [CrossRef] [PubMed]

145. Metzger, W.; Schimmelpfennig, L.; Schwab, B.; Sossong, D.; Dorst, N.; Bubel, M.; Görg, A.; Pütz, N.; Wennemuth, G.; Pohlemann, T.; et al. Expansion and differentiation of human primary osteoblasts in two- and three-dimensional culture. Biotech. Histochem. 2013, 88, 86-102. [CrossRef] [PubMed]

146. Sasaki, J.; Matsumoto, T.; Egusa, H.; Matsusaki, M.; Nishiguchi, A.; Nakano, T.; Akashi, M.; Imazato, S.; Yatani, H. In vitro reproduction of endochondral ossification using a 3D mesenchymal stem cell construct. Integr. Biol. 2012, 4, 1207-1214. [CrossRef] [PubMed]

147. Achilli, T.M.; Meyer, J.; Morgan, J.R. Advances in the formation, use and understanding of multi-cellular spheroids. Expert Opin. Biol. Ther. 2012, 12, 1347-1360. [CrossRef] [PubMed]

148. Kapur, S.K.; Wang, X.; Shang, H.; Yun, S.; Li, X.; Feng, G.; Khurgel, M.; Katz, A.J. Human adipose stem cells maintain proliferative, synthetic and multipotential properties when suspension cultured as self-assembling spheroids. Biofabrication 2012, 4, 025004. [CrossRef] [PubMed]

149. Zhang, S.; Liu, P.; Chen, L.; Wang, Y.; Wang, Z.; Zhang, B. The effects of spheroid formation of adipose-derived stem cells in a microgravity bioreactor on stemness properties and therapeutic potential. Biomaterials 2015, 41, 15-25. [CrossRef] [PubMed]

150. Ponomarev, I.V.; Kochneva, L.M.; Barnewitz, D. Effect of 3D chondrocyte culturing conditions on the formation of extracellular matrix in cartilage tissue-engineering constructs. Bull. Exp. Biol. Med. 2014, 156, 548-555. [CrossRef]

151. Weber, M.C.; Fischer, L.; Damerau, A.; Ponomarev, I.; Pfeiffenberger, M.; Gaber, T.; Götschel, S.; Lang, J.; Röblitz, S.; Buttgereit, F.; et al. Macroscale mesenchymal condensation to study cytokine-driven cellular and matrix-related changes during cartilage degradation. Biofabrication 2020. [CrossRef]

152. Damerau, A.; Pfeiffenberger, M.; Weber, M.C.; Burmester, G.R.; Buttgereit, F.; Gaber, T.; Lang, A. A Human Osteochondral Tissue Model Mimicking Cytokine-Induced Key Features of Arthritis In Vitro. Int. J. Mol. Sci. 2020, 22, 128. [CrossRef] [PubMed]

153. Pfeiffenberger, M.; Damerau, A.; Ponomarev, I.; Bucher, C.H.; Chen, Y.; Barnewitz, D.; Thöne-Reineke, C.; Hoff, P.; Buttgereit, F.; Gaber, T.; et al. Functional scaffold-free bone equivalents induce osteogenic and angiogenic processes in a human in vitro fracture hematoma model. J. Bone Min. Res. 2021. [CrossRef] [PubMed]

154. Ryu, N.E.; Lee, S.H.; Park, H. Spheroid Culture System Methods and Applications for Mesenchymal Stem Cells. Cells 2019, 8, 1620. [CrossRef] [PubMed]

155. Lee, D.; Pathak, S.; Jeong, J.-H. Design and manufacture of 3D cell culture plate for mass production of cell-spheroids. Sci. Rep. 2019, 9, 13976. [CrossRef]

156. Wagegg, M.; Gaber, T.; Lohanatha, F.L.; Hahne, M.; Strehl, C.; Fangradt, M.; Tran, C.L.; Schonbeck, K.; Hoff, P.; Ode, A.; et al. Hypoxia promotes osteogenesis but suppresses adipogenesis of human mesenchymal stromal cells in a hypoxia-inducible factor-1 dependent manner. PLoS ONE 2012, 7, e46483. [CrossRef]

157. Yang, D.C.; Yang, M.H.; Tsai, C.C.; Huang, T.F.; Chen, Y.H.; Hung, S.C. Hypoxia inhibits osteogenesis in human mesenchymal stem cells through direct regulation of RUNX2 by TWIST. PLoS ONE 2011, 6, e23965. [CrossRef]

158. Xu, N.; Liu, H.; Qu, F.; Fan, J.; Mao, K.; Yin, Y.; Liu, J.; Geng, Z.; Wang, Y. Hypoxia inhibits the differentiation of mesenchymal stem cells into osteoblasts by activation of Notch signaling. Exp. Mol. Pathol. 2013, 94, 33-39. [CrossRef]

159. Li, Q.; Yu, B.; Yang, P. Hypoxia-induced HMGB1 in would tissues promotes the osteoblast cell proliferation via activating ERK/JNK signaling. Int. J. Clin. Exp. Med. 2015, 8, 15087-15097.

160. Park, J.H.; Park, B.H.; Kim, H.K.; Park, T.S.; Baek, H.S. Hypoxia decreases Runx2/Cbfa1 expression in human osteoblast-like cells. Mol. Cell. Endocrinol. 2002, 192, 197-203. [CrossRef] 
161. Baptista, L.S.; Kronemberger, G.S.; Côrtes, I.; Charelli, L.E.; Matsui, R.A.M.; Palhares, T.N.; Sohier, J.; Rossi, A.M.; Granjeiro, J.M. Adult Stem Cells Spheroids to Optimize Cell Colonization in Scaffolds for Cartilage and Bone Tissue Engineering. Int. J. Mol. Sci. 2018, 19, 1285. [CrossRef] [PubMed]

162. Sankar, S.; Sharma, C.S.; Rath, S.N. Enhanced osteodifferentiation of MSC spheroids on patterned electrospun fiber mats-An advanced 3D double strategy for bone tissue regeneration. Mater. Sci. Eng. C 2019, 94, 703-712. [CrossRef]

163. Mandrycky, C.; Wang, Z.; Kim, K.; Kim, D.H. 3D bioprinting for engineering complex tissues. Biotechnol. Adv. 2016, 34, 422-434. [CrossRef] [PubMed]

164. Jakab, K.; Neagu, A.; Mironov, V.; Markwald, R.R.; Forgacs, G. Engineering biological structures of prescribed shape using self-assembling multicellular systems. Proc. Natl. Acad. Sci. USA 2004, 101, 2864-2869. [CrossRef] [PubMed]

165. Daly, A.C.; Kelly, D.J. Biofabrication of spatially organised tissues by directing the growth of cellular spheroids within $3 \mathrm{D}$ printed polymeric microchambers. Biomaterials 2019, 197, 194-206. [CrossRef] [PubMed]

166. Filipowska, J.; Tomaszewski, K.A.; Niedźwiedzki, Ł.; Walocha, J.A.; Niedźwiedzki, T. The role of vasculature in bone development, regeneration and proper systemic functioning. Angiogenesis 2017, 20, 291-302. [CrossRef] [PubMed]

167. Rauh, J.; Milan, F.; Günther, K.P.; Stiehler, M. Bioreactor systems for bone tissue engineering. Tissue Eng. Part B Rev. 2011, 17, 263-280. [CrossRef] [PubMed] 